\title{
PENGUATAN PENDIDIKAN AGAMA ISLAM PADA MADRASAH ALIYAH DI KUDUS
}

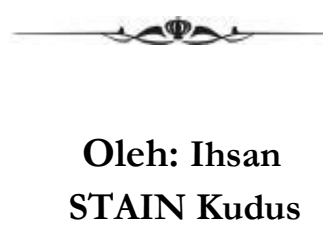

\begin{abstract}
Abstrak
Secara politis dan yuridis eksistensi madrasah sebagai lembaga pendidikan semakin kokoh dengan keluarnya Undang-Undang No. 2 Tahun 1989 dan Undang-Undang No. 20 Tahun 2003 beserta berbagai regulasi turunannya. Satu sisi regulasi tersebut telah menghantarkan madrasah pada posisi setara dan sederajat bahkan sama dengan sekolah umum. Namun pada sisi lain kedudukan tersebut menghadapkan madrasah pada tantangan dan dilema yang sulit terutama bila dikaitkan dengan kondisi objektifnya. Dampak secara umum dari status baru tersebut, setidaknya menurut beberapa kalangan tertentu, adalah menurunnya kemampuan/ penguasaan ilmu agama para lulusan madrasah. Fakta ini sulit untuk dihindarkan karena disamping harus tetap mengajarkan ilmu-ilmu agama, madrasah dituntut juga harus mengajarkan ilmu-ilmu umum sama dengan sekolah umum. Secara jujur harus diakui, madrasah adalah model pendidikan alternatif karena memiliki nilai plus dibandingkan dengan sekolah, yaitu pendidikan agama Islam yang relatif memadai. Namun keunggulan komperatif tersebut berpeluang hilang manakala problem dan dilema tersebut tidak dicarikan solusi yang tepat.
\end{abstract}

Kata Kunci : Madrasah, Kurikulum PAI, Penguatan Kepesantrenan 
Ihsan

\section{A. Pendahuluan}

Secara historis, madrasah sebagai lembaga pendidikan merupakan modernisasi transformasi lembaga pendidikan Islam tradisional, pesantren. ${ }^{1}$ Sedangkan secara kultural, pesantren adalah bentuk adaptasi dan islamisasi sistem pendidikan pra Islam, masa Hindu-Budha. ${ }^{2}$ Sebagai lembaga pendidikan dan sekaligus lembaga keagamaan (da'wah) ${ }^{3}$ dengan tradisi besarnya (great tradition), ${ }^{4}$ pesantren telah membuktikan kiprahnya dalam ikut mencerdaskan kehidupan umat. Namun, seiring berjalannya waktu, pesantren sebagai lembaga pendidikan dipandang kurang atau belum mampu membekali para santrinya dengan kompetensi praktis untuk berkarya, terutama untuk sektor formal. ${ }^{5}$ Fakta tersebut mendorong para tokoh muslim lulusan Timur Tengah tergerak untuk membuat format pendidikan baru dengan mengadopsi sistem persekolahan Barat dengan nama madrasah.

Perjuangan untuk mendapatkan pengakuan akan kesetaraan dan kesederajatan, mulai mendapatkan hasil, terutama pada era Orde Baru, setelah eksistensi madrasah mulai mendapatkan perhatian dari pemerintah di bawah naungan, pengelolaan serta pengawasan Kementerian Agama. Secara politis dan yuridis eksistesi tersebut menjadi semakin kuat dengan lahirnya Undang-Undang Nomor 2 Tahun 1989 tentang Sistem Pendidikan Nasional, dan Peraturan Pemerintah Nomor 28 dan 29 Tahun 1990 dimana madrasah mendapat predikat atau nama baru sebagai "sekolah umum yang berciri khas Islam".Eksistensi madrasah secara yuridis semakin kokoh dengan keluarnya Undang-undang Nomor 20 Tahun 2003, dimana antara madrasah dan sekolah memiliki kedudukan yang sama.

${ }^{1}$ Nurcholis Madjid, Bilik-Bilik Pesantren (Jakarta: Paramadina,1997),23. Lihat: Supaat, Model transformasi Madrasah sebagai Sekolah Umum Berciri Khas Islam, 2009, hlm. 110-135

${ }^{2}$ M.Habib Moestopo, Kebudayaan Islam di Jawa Timur: Kajian Beberapa Unsur Budaya Masa Peralihan (Yogyakarta: Jendela, 2001),150. Lihat juga: Sri Sutjiatiningsih \& Slamet Kutoyo, Sejarah Pendidikan Daerah Jawa Timur (Surabaya: Proyek Inventarisasi dan Dokumentasi Kebudyaan Daerah, 1986), hlm. 51.

3 Joko Sayono, "Historiografi Pesantren: Perspektif Metodologis antara Ada dan Tiada", Makalah, 2001, hlm. 3.

${ }^{4}$ Martin Van Bruinessen, Kitab Kuning Pesantren dan Tarekat: Tradisi-Tradisi Islam di Indonesia (Bandung: Mizan, 1995), 17. Paramadina, 1997), hlm. 23.

${ }^{5}$ Steenbrink, K. A., Pesantren madrasah sekolah: Pendidikan Islam dalam kurun modern. (Jakarta, LP3ES, 1986). 
Pembedaan, pada madrasah mata pelajaran pendidikan agama lebih banyak dibandingkan dengan sekolah umum.

Secara Nasional, sebagai sekolah umum dengan ciri khas Islam, madrasah diharapkan menjadi lembaga pendidikan plus dengan keunggulan komparatifnya, yaitu penekanan yang signifikan pada pendidikan agama dan akhlak (moralitas), di samping tentu pada penguasaan mata pelajaran umum. Dengan ciri khas tersebut diharapkan madrasah mampu menjadi "pendidikan alternatif" di tengah kegelisahan masyarakat akan kurangnya pemahaman nilai agama dalam kehidupan sehari-hari. Hal positif lain yang mendukung keunggulam madrasah adalah kenyataan kecenderungan new attachment kepada Islam dan lahirnya muslim rising middle class pada masyarakat yang semakin berusaha mendapatkan pendidikan Islam yang berkualitas bagi anak-anaknya. ${ }^{6}$ Fakta ini sekaligus menjadi peluang dan tantangan bagi madrasah untuk mampu memenuhi harapan para stakeholder, khususnya orang tua murid yang menghendaki anak-anaknya memperoleh pengetahuan agama dan umum secara memadai khususnya untuk tingkat Aliyah (MA).

Problem dan sekaligus menjadi kegelisahan terkait dengan output MA yang masih dan terus dirasakan oleh MA adalah rendahnya kemampuan atau kompetensi keagamaan (penguasaan pengetahuan agama Islam), sehingga ciri khas Islam sebagai identitas dan jati diri madrasah menjadi tidak atau kurang kelihatan secara maksimal. Oleh karena itu, tidak mengherankan jika masyarakat menilai sebagian besar lulusan MA saat ini kehilangan jati diri kemadrasahannya sesuai konteks historis kelahirannya sebagai lembaga pendidikan kader calon ulama. Sementara penguasaan atau capaian hasil belajar bidang sains atau pengetahuan umum jauh ketinggalan bila dibandingkan SMA.

Untuk mempertahankan, mengejar ketertinggalan dan melengkapi kekurangan tersebut muncul fenomena di beberapa MA di Kudus yang menyelenggarakan sistem pendidikannya dengan mengadopsi sistem pendidikan pesantren. Langkah ini ditempuh antara lain untuk menambah jam pembelajaran sehingga memungkinkan

${ }^{6}$ Azyumardi Azra, Surau: Pendidikan Islam Tradisional dalam Transisi dan Modernisasi (Jakarta: Logos, 2003), hlm. 54. 
proses penguatan dan pengayaaan materi kurikuler sesuai standar isi. Khusus terkait materi Pendidikan Agama Islam, sistem ini dijadikan sebagai media untuk implemntasi pengembangan kurikulum, baik dalam arti subject matter maupun sistem dan model pembelajarannya.

Bagaimana desain dan implementasi program pendidikan agama Islam yang memungkinkan penguatan kembali pendidikan agama Islam yang maksimal. Atas dasar pertimbangan dan realitas tersebut, sebagai praktisi dan akademisi penulis terdorong untuk menjawab fenomena tersebut sekaligus menawarkan solusi atas ber-bagai problem dan kendala yang dihadapi oleh lembaga pendidikan Islam.

\section{B. Hasil Penelitian}

\section{Problematika MA di Kudus}

Rumusan implementasi? "pendidikan yang dijiwai suasana keagamaan" di seluruh MA di Kudus, sesuai kapasitas dan konteks masing-masing relatif sudah terumuskan dan terlaksana. Karena pemahaman untuk rumusan ini lebih mudah untuk dipahami dan diwujudkan dalam praktik. Semua MA di Kudus, dalam rangka mewujudkan suasana keagamaan ini dilaksanakan dalam bentuk penciptaan lingkungan madrasah dengan berbagai kegiatan yang bersumber dari nilai atau ajaran Islam yang berujung pada terciptanya budaya yang Islami, mulai dari cara berpakaian, bertutur kata, pergaulan sampai pada berbagai bentuk latihan atau praktik ritual keagamaan. Secara

\footnotetext{
${ }^{7}$ Kunandar, Guru Profesional Implementasi Kurikulum Tingkat Satuan Pendidikan (KTSP) dan Sukses dalam Serti $\square$ kasi Guru, ( Jakarta, RajaGra $\square$ ndo Persada, 2007), 211. Dalam Oxford Advance Learner's Dictionary dikemukakan bahwa implementasi adalah "put something into effect" atau penerapan sesuatu yang memberikan efek. Berdasarkan de $\square$ nisi implementasi tersebut, maka implementasi kurikulum dapat dide $\square$ nisikan seb-agai suatu proses penerapan ide, konsep, dan kebijakan kurikulum dalam suatu aktivi-tas pembelajaran sehingga peserta didik menguasai seperangkat kompetensi tertentu sebagai hasil interaksi dengan lingkungan. Pengertian-pengertian tersebut menperli-hatkan bahwa kata implementasi bermuara pada aktivitas,adanya aksi, tindakan, atau mekanisme suatu sistem. Ungkapan mekanisme mengandung arti bahwa implementasi bukan sekedar aktivitas, tetapi suatu kegiatan yang terencana dan dilakukan secara sungguh-sungguh berdasarkan acuan norma tertentu untuk mencapai tujuan kegiatan. Oleh karena itu implementasi tidak berdiri sendiri, tetapi dipengaruhi oleh objek beri-kutnya yakni kurikulum. Lihat: Syafruddin Nurdin, Guru Profesional dan Implementasi Kurikulum, ( Jakarta, Ciputat Press, 2002),70.
} 
teknis pelaksanaan kegiatan tersebut ada yang terstruktur dalam format kurikuler, hiden curriculum maupun ekstra kurikuler. ${ }^{8}$

Persoalan semakin serius jika dikaitkan dengan kapasitas madrasah sebagai lembaga pendidikan dalam konteks dan mainstream pendidikan nasional. Fakta inilah yang kemudian menghadapkan madrasah dengan berbagai problem dan tantangan dalam mewujudkan visi dan tujuan pendidikannya. Karena, masing-masing madrasah memiliki kapasitas yang sangat variatif dilihat dari variabel: kapasitas manajemen, kurikulum, keterbatasan sumber daya manusia, orientasi akademik dan dikotomi ilmu, konteks Ujian Nasional (UN), serta konteks otonomi daerah. Di sisi lain, masing-masing madrasah memiliki karakter yang berbeda jika ditinjau dari: aspek sejarah berdirinya, latar belakang para tokoh pendiri, kapasitas manajemen, status kelembagaan, latar belakang pedidikan para pengajar, kitab yang dijadikan sebagai acuan dalam pembelajaran agama Islam, jumlah muatan lokal (kurikulum atau mapel lokal) dan suasana pembelajaran dan lingkungan pendidikan.

\section{Tipologi MA di Kudus}

Atas dasar identifi kasi problem dan latar yang berbeda, MA di Kudus dapat dikelompokkan menjadi dua kategori, yaitu MA yang lahir sebelum dan sesudah keluarnya Undang-Undang Nomor 2 Tahun 1989. Pembedaan ini menjadi penting tidak hanya sekedar untuk mengetahui usia suatu MA, tetapi yang lebih penting adalah karena keluarnya undang-undang tersebut merupakan momentum besar bagi pengakuan madrasah dalam sistem pendidikan nasional. Problem utama yang dihadapi oleh madrasah sebelum lahirnya Undang-undang tersebut adalah legitimasi, maka tema perjuangan umat Islam pada saat itu (sebelum keluar Undang-undang) adalah pengakuan akan kesetaraan dan kesederajatan. Penyebab utama tidak diakuinya madrasah (lulusan madrasah) pada saat itu karena muatan isi kurikulum madrasah berbeda dengan sekolah umum, sehingga kompetensi lulusannya dianggap berbeda. Pada dataran praktis, terutama untuk sektor formal, lulusan madrasah tidak memperoleh

\footnotetext{
hlm.11

${ }^{8}$ Nasution, Pengembangan Kurikulum (Bandung: PT Citra Aditya Bakti,1993),
} 
Ihsan

hak-hak yang semestinya seperti yang diperoleh lulusan sekolah umum. Keadaan ini kemudian menjadi berubah dengan keluarnya undang-undang tersebut, dengan konsekuensi muatan isi kurikulum madrasah harus sama dengan kurikulum sekolah umum. Perubahan tersebut, seperti digariskan dalam Peraturan Pemerintah Nomor 29 Tahun 1990 dan Surat Keputusan Menteri Pendidikan dan Kebudayaan Nomor 0489/U/1992, kurikulum madrasah harus $100 \%$ sama dengan sekolah umum. ${ }^{9}$

Dalam statusnya sebagai lembaga pendidikan Islam, maka muatan isi kurikulum madrasah pada awal kelahirannya, sesuai visi dan tujuannya adalah ilmu-ilmu agama ('ulum al-din), ilmu pengetahuan umum hanya sebagai pelengkap atau tambahan. Keadaan inilah yang menjadikan MA di Kudus yang lahir sebelum dan sesudah tahun 1989 memiliki karakter yang berbeda. MA yang lahir (setidaknya embrio kelahirannya) sebelum tahun 1989 karakter dan orientasi keagamaanya sangat kuat, sehingga secara kelembagaan memiliki kesamaan substansial dengan sistem pendidikan pesantren. Sedangkan MA yang lahir sesudah tahun 1989 kurikulum dan sistem pembelajarannya sepenuhnya mengadopsi sistem persekolahan dengan pengayaan bidang Pendidikan Agama Islam (PAI). Dilihat dari kompetensi dan penguasaan ilmu agama Islam MA kategori ini tidak jauh berbeda dengan lulusan SMA. Hal ini dapat dilihat dalam struktur kurikulum, jenis mata pelajaran, sistem pembelajaran, dan orientasi kelembagaan.

Hanya ada 2 dari 29 MA di Kudus yang berstatus negeri, selebihnya adalah MA yang lahir dan berkembang atas prakarsa dan inisiatif masyarakat. Dari 2 MA berstatus negeri itupun salah satunya (MAN 1 Kudus) melalui proses penegerian, artinya awal kelahirannya adalah atas prakarsa masyarakat. Sementara yang lainnya adalah (MAN 2 Kudus) hasil konversi dari PGAN Kudus. Sebagai lembaga pendidikan yang didirikan oleh masyarakat, maka visi dan

${ }^{9}$ Secara jelas dinyatakan bahwa kurikulum pendidikan menengah yang berlaku secara nasional ditetapkan oleh menteri atau meneteri lain berdasarkan pelimpahan wewenang. Lembaga sekolah/madrasah dapat menjabarkan dan menambahkan mapel sesuai dengan keadaan lingkungan dan ciri khasnya, dengan tidak mengurangi kurikulum yang berlaku secara nasional. Lihat: Peraturan Pemerintah No. 29, Tahun 1990, Pasal 15, ayat 4,5,6 dan 7 . 
cita-cita para tokoh pendiri MA swasta tersebut sangat mempengaruhi arah dan perkembangan MA tersebut.

Hal penting terkait dengan para tokoh tersebut adalah latar belakang para tokoh pendiri suatu MA. Latar belakang yang dimaksud di sini adalah latar belakang pendidikan dan profesi atau kedudukan sosial para tokoh tersebut di masyarakat. Hampir semua MA swasta di Kudus didirikan atas prakarsa tokoh agama (ulama) dan tokoh masyarakat pada tingkatan masing-masing. Semakin tinggi tingkat ketokohan (popularitas) para pendiri akan menjadi daya tarik bagi masyarakat untuk menyekolahkan anaknya ke suatu MA. Aspek ketokohan yang sangat diperhatikan oleh masyarakat adalah tingkat ke-ulama-an tokoh pendiri.

Hampir semua MA swasta di Kudus yang didirikan sebelum tahun 1989 tokoh pendirinya adalah para kyai (ulama) besar di Kudus, dengan latar belakang pendidikan pesantren, rata-rata memiliki pondok pesantren atau setidaknya memiliki forum pengajian tetap (majlis ta'lim) di masjid atau musholla. Latar belakang pendidikan pesantren inilah yang mewarnai visi akademik atau keilmuan yang dikembangkan dalam kurikulum MA. Karena terlalu banyaknya ilmu agama yang diberikan, MA jenis ini lebih mirip dengan pesantren dibanding madrasah.

Sedangkan MA yang berdiri setelah tahun 1989 sebagian besar didirikan oleh tokoh masyarakat (bukan kategori kyai/ulama) yang peduli terhadap pendidikan (Islam), bahkan beberapa di antara para tokoh pendiri MA ini adalah para pamong/perangkat desa. Meskipun demikian proses pendiriannya tetap melibatkan peran para ulama/kyai lokal. Dilihat dari tujuannya, pendirian MA jenis ini adalah:

(1) Menampung banyaknya lulusan MTs/SMP yang tidak tertampung di SMA/MA negeri atau MA swasta besar di perkotaan.

(2) Memberi kesempatan kepada golongan masyarakat menengah ke bawah dari pedesaan yang tidak mampu melanjutkan ke SMA/MA di perkotaan karena alasan ekonomi untuk bisa mengenyam pendidikan menengah.

(3) Memberi pendidikan agama Islam kepada masyarakat sebagai bagian dari tugas suci untuk menyebarkan/dakwah Islam. Atas dasar pertimbangan tujuan tersebut, maka kurikulum yang di- 
kembangkan untuk MA ini lebih sederhana dibandingkan dengan tipe MA yang didirikan oleh para ulama atau kyai. Pendidikan agama Islam yang diberikan untuk MA jenis ini sebatas sesuai dengan kurikulum sebagaimana standar pemerintah (Kementerian Agama). Kalau ada penambahan mata pelajaran ilmu agama, itu lebih bersifat pengayaan tidak sampai pada kualifi kasi tafaqquh fi al-din atau rashib fi al din (menguasai/ memahami agama secara mendalam).

Ditinjau dari kemampuan manajemen, kekuatan MA di Kudus dapat dikelompokkan menjadi maju, sedang, dan kurang. Indikatornya:1) ketersediaan dan kecukupan infrastruktur kependidikan, 2) ketersediaan dan kecukupan tenaga pendidik sesuai kualifi kasi dan kompetensi, dan 3) jumlah peserta didik. Ketiga faktor tersebut, faktor jumlah peserta didik menjadi dominan dan determinan dalam menentukan faktor pertama dan kedua. Semakin banyak jumlah siswa maka akan semakin tercukupi infrastruktur kependidikan dan terpenuhi jumlah guru yang dibutuhkan.

Sedangkan dari sisi status kelembagaannya, dikelompokkan menjadi MAN dan MAS. Pengelompokan MA menjadi negeri dan swasta ini tidak hanya dimaksudkan untuk melihat status kelembagaan yang berimplikasi pada aspek administratif (kapasitas manajemen) semata, tetapi yang lebih penting adalah terkait dengan aspek yang lebih mendasar yaitu visi akademik dan orientasi pembelajarannya, yang berujung kepada perbedaan substantif MAN dan MAS. Berbeda dengan MA negeri yang keberadaannya dalam banyak hal diatur, ditentukan dan difasilitasi oleh pemerintah, keha-diran dan keberadaan madrasah swasta di tengah-tengah masyara-kat benar-benar atas ide, prakarsa atau upaya dari masyarakat, termasuk dalam hal pembiayaan.

Pada satu sisi kemandirian madrasah swasta tersebut sangat positif dalam konteks kreasi dan inovasi, namun pada sisi lain kemandirian terutama dalam bidang pembiayaan justru menjadi kendala berat bagi madrasah swasta untuk melaksanakan kreasi dan inovasi sesuai tuntutan zaman.

Berdasarkan data yang penulis kumpulkan, ada perbedaan sig- 
nifikan antara MA negeri dan MA swasta dalam memahami dan memaknai ciri khas Islam. Untuk MA negeri implementasi ciri khas Islam diwujudkan dalam bentuk penjabaran rumpun PAI menjadi lima mata pelajaran, sedangkan untuk MA swasta penjabaran PAI menjadi lima mata pelajaran tersebut dianggap belum mampu mewujudkan jati diri dan roh MA sebagai lembaga pendidikan Islam. Oleh karenanya, perlu penambahan atau bahkan perombakan komposisi PAI tersebut dan melengkapinya dengan beberapa ilmu pendukung yang relevan (ilmu alat) yang dibutuhkan untuk kepentingan memahami teks sumber ajaran (al-Qur'an dan al-Hadith) dan berbagai kitab klasik yang relevan. Atas dasar pertimbangan inilah maka di beberapa MA yang berorientasi kuat ilmu-ilmu agama Islam materi dan sistem pembelajarannya hampir sama dengan pesantren. Hal ini berbeda dengan MA negeri yang sama dengan SMA, bila ada perbedaan hanyalah sedikit yaitu pada penjabaran PAI.

Hal lain yang berpengaruh besar terhadap visi dan jati diri MA swasta adalah keberadaan organisasi sosial keagamaan pendiri dan pengelolanya. Tidaklah mengherankan manakala orientasi MA ini sangat dipengaruhi oleh visi dan misi organisasi pendiri dan pengelolanya, bahkan dalam banyak hal faham keagamaan para tokoh pendirinya sangat mempengaruhi bahkan menentukan arah serta tujuan suatu MA. Karena sifatnya yang demikian, maka MA tidak hanya berfungsi sebagai lembaga pendidikan tetapi juga berfungsi sebagai media dan instrumen kaderisasi organisasi sosial keagamaan tertentu, sering disebut dengan lembaga pendidikan kader. Hal ini dapat dilihat dari rumusan visi-misi, sistem/model pengelolaan, dan struktur isi kurikulum yang dijadikan sebagai acuan pendidikan dan pengajarannya.

Berangkat dari empat faktor tersebut, dan realitas implementasi ciri khas Islam sebagaimana tercermin kegiatan inti kependidikannya (kurikulum/standar isi dan kompetensi lulusan/standar kompetensi lulusan), tipologi MA di Kudus penulis kategorikan sebagai model MA yang dilahirkan dari paradigma madrasah berbasis pesantren, adapaun jenis-jenis dari madrasah berbasis pesantren adalah: 
Ihsan

\section{a. Madrasah Pesantren (MP).}

Madrasah Pesantren (MP) adalah model pengelolaan MA, dimana secara operasional pengelolaan antara madrasah dan pesantren berada dalam satu sistem manajemen. Artinya, suatu MA tidak hanya secara fisik berada dalam lingkungan pesantren tetapi antara MA dan pesantren berada dalam satu struktur organisasi dan manajemen yang menyatu (integreted). Tujuan dari penyatuan sistem pengelolaan ini adalah agar semua proses pendidikan berada dalam suatu sistem yang memungkinkan semua kegiatan guru dan murid berada dalam satu alur dan paket program yang sama. Dari tiga model yang peneliti tawarkan, model ini yang paling ideal untuk sebuah proses pendidikan, tidak hanya untuk pendidikan Islam (madrasah) saja tetapi juga untuk semua lembaga pendidikan pada umumnya. Dengan sistem atau model ini akan tercipta proses pendidikan holistik yang akan melahirkan output dan outcome pendidikan berkualitas. Perhatikan gambar 5

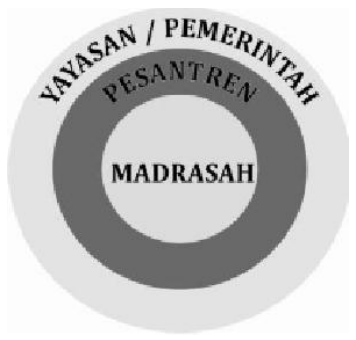

\section{Gambar 5 : Pola Integrasi Madrash Pesantren (MP) I}

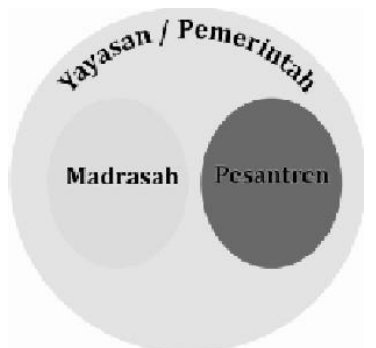

\section{Gambar 6 : Pola Integrasi Madrasah Pesantren (MP) II}

Seperti telah diuraikan pada kerangka konsep di atas, pada MP ada tiga aspek penting yang memungkinkan berlangsungnya proses 
pendidikan di MA yang berorientasi pada kualitas, yaitu aspek pengelolaan, aspek kurikulum dan aspek suasana keagamaan. Untuk memperjelas gambaran konsep MP, dapat diperhatikan skema 6

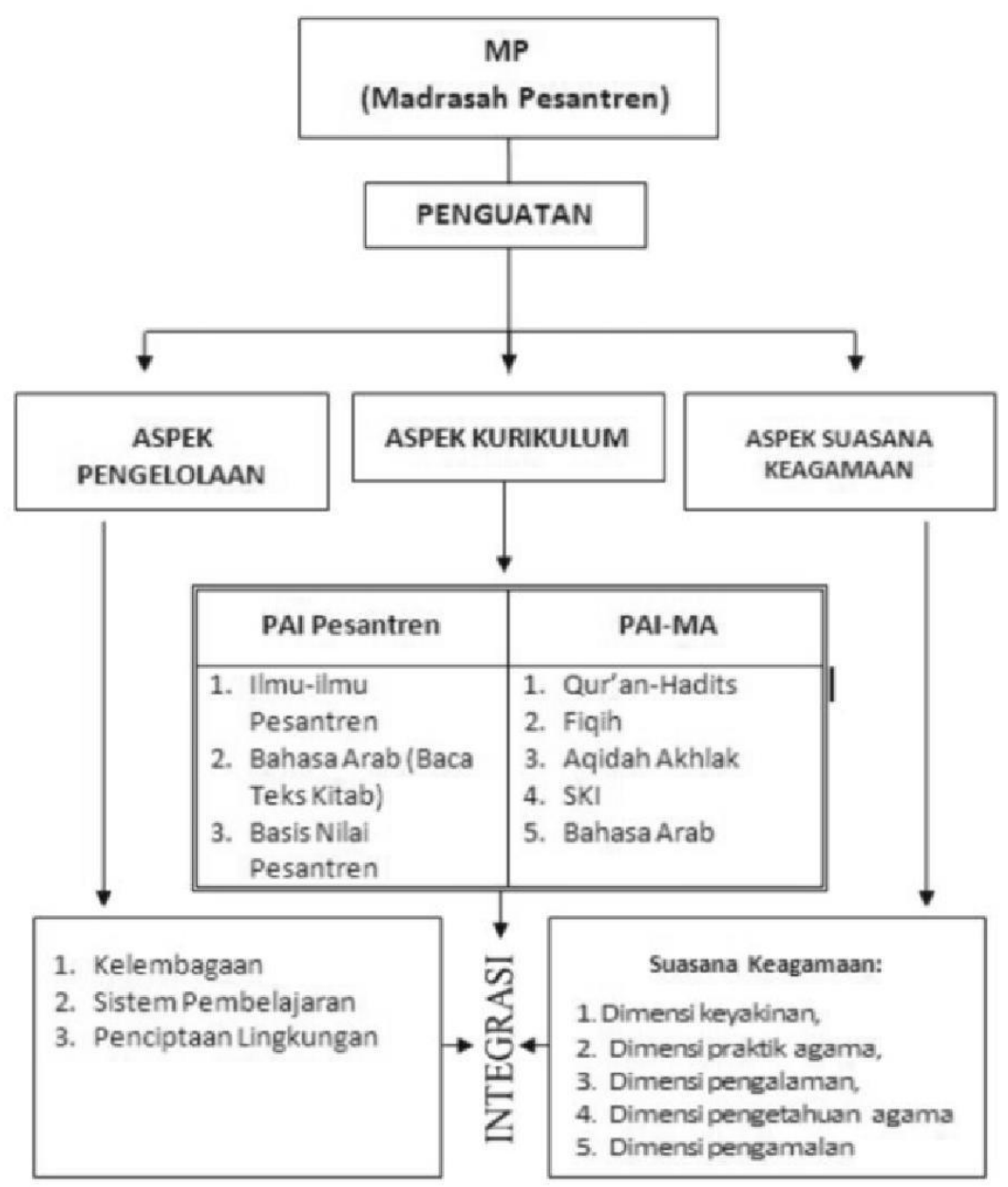

\section{Gambar 4 : Skema Model Madrasah Pesantren}

\section{b. Madrasah Lingkungan Pesantren (MLP).}

Madrasah yang berada di lingkungan Pesantren yang dising-kat MLP ini secara substantif memiliki kesamaan dengan model yang pertama, perbedaannya hanyalah terletak pada keberadaan pesantren secara pisik. Bila pada model pertama MA dan pesantren 
Ihsan

berada dalam satu sistem pengelolaan dan dalam satu kompleks pendidikan, untuk model yang kedua antara MA dan pesantren tidak berada dalam satu sistem manajerial. Pesantren yang di maksud disini adalah pesantren yang secara fisik berada dalam satu kawasan atau lingknguan di skitar lokasi MA. Model ini sekaligus menjadi alternatif bagi MA yang memiliki keterbatasan dalam penyiapan infrastruktur.

Karena berada di luar manajemn dan tidak berada dalam satu komplek pendidikan, langkah yang bisa ditempuh oleh para pengelola MA adalah dengan mengadakan kerja sama dengan pihak pengelola/pengasuh pesantren dalam hal materi (ilmu agama) yang diajarkan di pesantren. Oleh karennya, dari sudut pengelolaan kelembagaan model MLP ditempuh melalui kerjasama antara manajemen madrasah pada satu pihak dan manajemen pesantren pada pihak lain. Dengan kerja sama ini diharapkan sistem dan materi pendidikan yang dijarkan di pesantren bisa sejalan dan mendukung tema-tema yang diajarkan di MA. Sinergitas madrasah dan pesantren dapat diperhatikan pada gambar 8 dan 9 berikut ini.

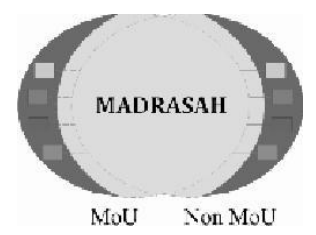

Gambar 8: Pola Sinergi Madrasah Lingkungan Pesantren (MLP) I

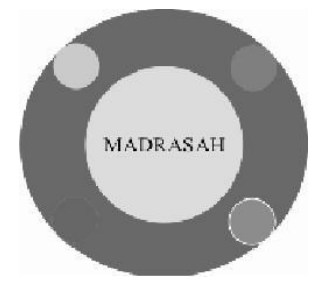

\section{Gambar 9 : Pola sinergi Madrasah Lingkungan Pesantren (MLP) II}

Dari sudut materi atau bahan yang diajarkan, rumusan verbalnya bisa jadi antara apa yang diajarkan di madrasah dan di pesantren 
berbeda. Namun substansi isi bahan yang diajarkan ada titik temu. Meskipun dari sudut kelembagaan antara madrasah dan pesantren merupakan unit organisasi atau lembaga yang berbeda, namun pembelajaran di pesantren didesin dalam rangka penguatan (empowering) terhadap materi yang diajarkan di madrasah. Karena berbeda lembaga maka antara keduanya hubungannya bersifat koordinatif dalam rangka menjalin sinergi demi menghindarkan terjadinya ketidaksesuaian isi dari materi pembelajaran. Karena merupakan unit organisasi yang berbeda, maka model pmanajemen/kepemimpinan antara madrasah dan pesantren tidak harus menyatu, karena untuk menyatu membutuhkan beaya inftrastruktur yang mahal. Akan tetapi antara madrasah dan beberapa pesantren yang berada di lingkungannya ada kerjasama dan koordinasi.

Kerjasama dimaksud terkait dengan materi kurikulum, tata tertib, jadwal kegiatan, dan hal-hal teknis lainnya. Dalam sistem pendidikan dan pembelajaran, secara operasional pembelajaran di pesantren berjalan sesuai dengan karakter dan materi masing-masing pesantren. Dengan asumsi bahwa pembelajaran di pesantren berorientasi pada ulum al-din, maka hasil pembelajaran tersebut otomatis akan memperkaya dan melengkapi materi agama Islam di kurikulum madrasah. Dalam rangka penciptaan lingkungan yang kondusif untuk belajar dan Islami, pesantren yang berada di lingkungan madrasah tersebut berjalan sesuai dengan kultur dan nilai yang ada dan berjalan selama ini. Dengan kata lain pengelola pesantren memiliki otonomi dan deskresi untuk melaksanakan kegiatan pendidikan dan pengajarannya, khususnya untuk materi ulum al-din. Output yang diharapkan dari sistem ini adalah penciptakan pribadi siswa/santri yang berakhlaqul karimah.

Terkait dengan pembelajaran untuk penguatan, model ini setidaknya untuk Kudus, lebih visibel untuk dilakukan karena sudah "diterapkan" oleh beberapa madrasah. Kekuranganya hanya satu, selama ini antara madrasah dan pesantren tidak ada kerjasama atau koordinasi, sehingga terkesan siswa yang nyantri di pesantren lebih mirip mencari pemondokan untuk tempat tinggal. Kerjasama dalam konteks ini ditujukan untuk kepentingan koordinasi dan sinergi kegiatan. Langkah ini sangat dimungkinkan dan mudah untuk dilak- 
Ihsan

sanakan karena apapun bentuknya antara madrasah dan pesantren secara historis memiliki ikatan dan sejarah panjang, terutama dalam konteks dakwah Islamiyah. Adapun aspek dan tujuan dari kerjasama dan koordisnasi ini meliputi:

\section{c. Madrasah Sistem Nilai Pesantren (MSNP).}

Konsep model ketiga ini didasarkan atas asumsi bahwa sistem pendidikan pesantren dengan meteri dan kulturnya dipandang cocok atau sesuai dengan karakter MA, terutama dalam mewujudkan ciri khas Islam. Perhatikan gambar 10 berikut ini.

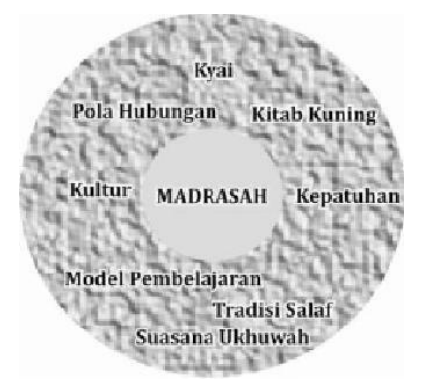

\section{Gambar 10 : Pola Adopsi Sistem Nilai Pesantren (MSNP)}

Sebagaimana diketahui, pada pesantren ada unsur-unsur yang secara kultural sejalan dan mendukung tercapainya tujuan pendidi-kan dengan ciri khas Islam. Seperti keberadaan kiai sebagai figur panutan, masjid sebagai pusat kegiatan pendidikan dan ibadah, pengajaran kitab kuning sebagai sumber pengetahuan agama Islam, dan asrama sebagai media penciptaan suasana sosial keberagamaan, lengkap dengan kondisi lingkungan pesantren sebagai sub kultur masyarakat sekitar. Untuk mempermudah dan memperjelas anatomis unsurunsur lingkungan madrasah dan pesantren serta adobsi sistemik dari sistem nilai dan tradisi pesantren, maka berikut akan penulis gambarkan dalam bentuk skema. 


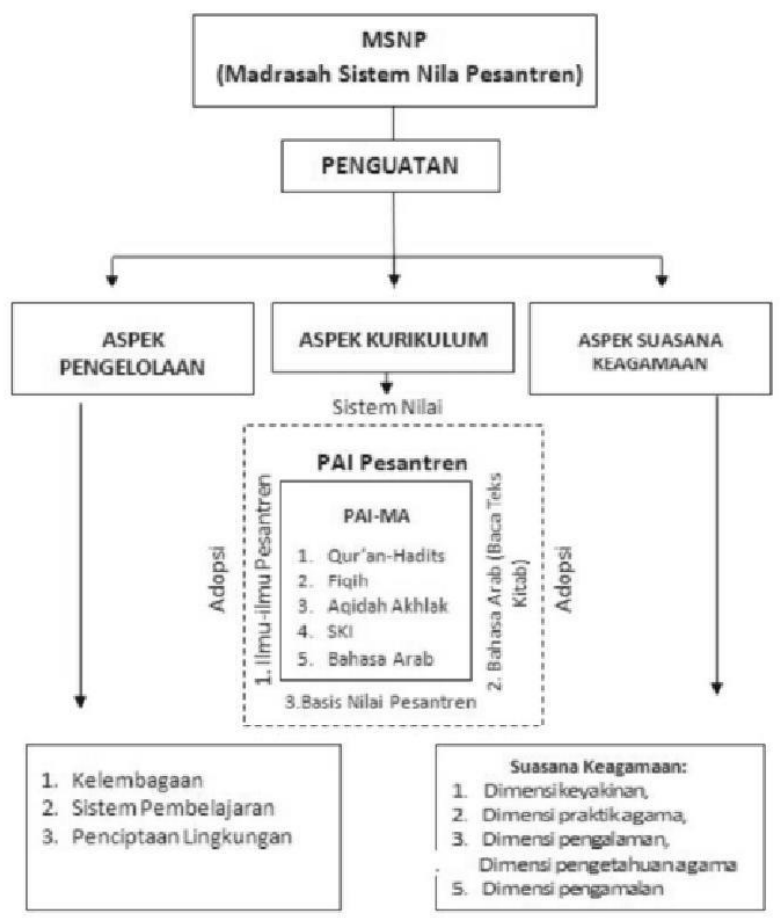

\section{Gambal 11: Skema Madrasah Sistem Nilai Pesantren}

Sebagaimana dua model penguatan Pendidikan Agama Islam (PAI) berbasis Pesantren sebelumnya, maka model ketiga ini juga memiliki tiga aspek pokok sebagai komponen yang akan menjadi jelas dalam model dimaksud, yaitu: aspek pengelolaan, aspek kurikulum dan aspek suasana keagamaan.

\section{Komparasi antar Model Madrasah Berbasis Pesantren sebagai Model Penguatan PAI}

Setelah melakukan elaborasi atas beberapa tawaran model madrasah berbasis pesantren sebagai model penguatan pendidikan agama Islam, maka penulis akan membuat komparasi antar-ketiganya. Tujuannya jelas, yakni mencari kelemahan dan kekuatan antar-model, serta mencari peluang bagi "irisan konseptual" antarmodel tersebut guna lebih mendekatkan tulisan ini kepada cita-cita madrasah berbasis pesantren. 
Ihsan

Seperti diketahui, tesis utama penelitian ini ialah perlunya perumusan ulang pendidikan MA berbasis pesantren. Dalam kaitan ini, basis tersebut mengacu pada empat hal; basis ontologis, basis epistemologis, basis pedagogis, dan basis kultural. Pertama, basis ontologis. Basis ini hendak memberikan dasar ontologis dari pendidikan Islam. Yakni suatu ontologi pendidikan yang menempatkan manusia dalam ruang ontologi keIslaman. Dalam kaitan ini, pendidikan Islam terkait dengan status hakiki manusia sebagai hamba Allah yang butuh mendekatkan diri, agar mampu berperan sesuai dengan kehendak Allah. Jadi ontologi pendidikan Islam akhirnya merupakan proses pembelajaran agar manusia bisa lebih mengenali tujuan penciptaannya, serta mengetahui tugas hidupnya. Dari sini pendidikan Islam akhirnya memuara pada dua status manusia, yakni manu-sia sebagai "abdullah" dan manusia sebagai "khalifatullah".

Dari uraian ini kita menjadi mafhum mengapa model Madrasah Lingkungan Pesantren (MLP) belum ideal. Karena, madrasah berbasis pesantren tidak hanya dipahami secara teritorial. Artinya, madrasah berbasis pesantren bukan hanya sekedar persoalan letak madrasah yang secara geografis berada di dalam lingkungan pesantren. Hal ini sudah banyak kita temukan pada lembaga pesantren yang mendirikan madrasah di dalamnya. Motivasi pendirian tersebut sangat beragam, mulai dari motivasi bahwa pesantren memiliki dan menyadari kelemahannya sebagai lembaga pendidikan tradisional, sehingga perlu mendirikan madrasah yang merupakan proto-type dari lembaga pendidikan modern. Oleh karena itu, madrasah sebagai lembaga pendidikan modern, ingin melakukan modernisasi pesantren malaui jalur pendirian lembaga madrasah.

Sementara itu, gagasan madrasah berbasis pesantren justru sebaliknya. Ia merupakan arus balik tradisi, di mana pesantren hendak mengembalikan madrasah ke akar tradisi pendidikan Islam. Jadi ia pertama-tama merupakan kehendak normatif, baru setelah itu menjadi kehendak pedagogis. Artinya, gagasan ini bersifat normatif sebab ia lahir dari keprihatinan normatif akan tercerabutnya madrasah dari nilai kepesantrenan. Cara pikir tersebut, tentu saja telah melampaui kritik pendidikan dan kritik kebudayaan. Dalam kritik ini, tradisi mengarus-balik, mengritik modernitas, dan hen- 
dak mengembalikannya ke dasar tradisi tersebut. Ia menjadi kritik kebudayaan, karena telah melakukan kritik kemasyarakatan yang dibentuk oleh pola modernis dalam sistem pendidikan nasional kita. Tentu madrasah tidak bermasalah dalam dirinya sendiri. Ia memiliki kelemahan, karena ia bagian dari sistem pendidikan formal kita yang banyak memiliki kelemahan. Pada titik ini, MLP tidak memenuhi syarat normatif tersebut, karena ia tidak berangkat dari kritik kebudayaan: kritik tradisi atas modernitas. Oleh karenanya, di dalam MLP, terjadi pemilahan antara madrasah dan pesantren, sehingga keduanya terpisah, baik secara kelembagaan, maupun sistem pendidikan. Yang penulis maksud sebagai kelembagaan di sini berarti kelembagaan pendidikan, sebab bisa saja MLP berada dalam satu lembaga, yayasan misalnya, namun dalam pelembagaan pendidikan, mereka tidak sama, dan tidak menyatu.

Hanya saja, model MLP memiliki nilai positif, dari segi geoinstitusional. Artinya, karena secara geografis dan institusional telah menyatu antara madrasah dan pesantren, maka gagasan madrasah berbasis pesantren bisa diwujudkan. Tentu ia memerlukan banyak perubahan mendasar, seperti perubahan paradigma pendidikan Islam, perubahan pedagogis, perubahan kurikulum, dan perubahan lingkungan khusus untuk lingkungan pendidikan. MLP telah memilikinya sebab sebagian besar murid madrasah pastilah pula santri pesantren tersebut. Hanya saja tidak mudah untuk melakukan perubahan paradigma yang berdampak pada perubahan pedadogi. Ia terkait dengan pola pikir masyarakat yang sudah begitu mapan, serta sistem pendidikan nasional yang begitu stabil. Makanya, gagasan madrasah berbasis pesantren ini selain bersandar pada kesadaran dan pergerakan dari masyarakat madrasah-pesantren. Juga terkait dengan perjuangan struktural dalam perombakan sistem pendidikan madrasah, agar bersedia menjadikan kepesantrenan sebagai basis pendidikan Islam secara nasional.

Sementara itu, untuk madrasah sistem nilai pesantren (MSNP) persoalannya agak beda. Model inipun hampir sama dengan MLP. Ia memiliki kelemahan juga kekuatan. Jika MLP kekuatannya terletak pada kesatuan fisik antara madrasah dan pesantren. Sementara dalam MSNP, kekuatannya terletak pada sebagian sistem nilai 
Ihsan

pesantren di madrasah.

Kelemahan yang terdapat di MSNP ialah belum bersatunya pesantren dan madrasah secara kelembagaan, dengan pesantren sebagai basis kulturalnya. Sebab secara manajerial pendidikan, MSNP sangat potensial bagi gagasan madrasah berbasis pesantren tersebut. Manajemen pendidikan MSNP telah mengacu pada kurikulum pendidikan pesantren. Hal ini cukup sebagai modal bagi gagasan madrasah berbasis pesantren. Maka untuk MSNP, langkah menuju madrasah berbasis pesantren tinggal setahap. Yakni penyatuan institusional antara madrasah dan pesantren. Tentu hal ini membutuhkan biaya besar, jika dibanding dengan MLP, sebab secara fisik, MSNP haruslah mendirikan pesantren di dalam lingkungan madrasah, sebagai basis kultural bagi pendidikan madrasah.

Dari komparasi ini, kita bisa menyimpulkan bahwa model MP yang paling ideal. Sayangnya model ini belum terwujud, khususnya di Kabupaten Kudus. Hal ini terjadi karena belum adanya kesadaran akan perlunya gerakan kembali ke tradisi pesantren, sebagai solu-si dari ketercerabutan nilai-nilai dasar pendidikan Islam yang ada di madrasah. Yang realistis kemudian ialah berangkat dari realitas, yakni realitas MLP dan MSNP. Artinya, gagasan madrasah berbasis pesantren bisa berangkat dari dua model kelembagaan tersebut yang belum ideal, tetapi bisa menjadi pijakan bagi cita-cita madrasah berbasis pesantren. Hal ini bisa diwujudkan melalui penambalan atas kelemahan dari masing model. Kepada MLP, yang perlu dibangun adalah kesatuan sistemik kepesantrenan. Artinya, kesatuan yang bersifat fi sik kelembagaan, perlu disempurnakan melalui kesatuan sistemik pendidikan Islam berbasis kepesantrenan. Sementara itu bagi MSNP, yang perlu dibangun adalah kesatuan kelembagaan pendidikan. Hal ini sebagai usaha penyempurnaan, karena dalam MSNP, sistem nilai pesantren telah menjadi bagian dari tradisi pendidikannya.

\section{Penutup}

Penguatan Pendidikan Agama Islam (PAI) pada Madrasah Aliyah dengan basis Pesantren, bisa disebut sebagai realitas konseptual. Artinya, gagasan ini bersifat konseptual. Sehingga apa yang disebut sebagai Madrasah Berbasis Pesantren bisa saja tidak menjadikan 
kesatuan kelembagaan antara madrasah dan pesantren. Term basis dalam Madrasah Berbasis Pesantren bisa bersifat konseptual, di mana sistem nilai dan sistem pendidikan pesantren telah dijadikan basis ontologis, epistemologis dan pedagogis dari sistem pendidikan madrasah, tanpa harus ada pembangunan pesantren di dalam madrasah. Hal ini terjadi sebab sebagai gagasan, Madrasah Berbasis Pesantren lahir dari krisis konseptual pendidikan Islam madrasah yang semakin jauh dari sistem nilai dan kultur pendidikan Islam salafi dan berikhtiar menawarkan solusi konseptual. Salah satu wujud dari sifat konseptual Madrasah Berbasis Pesantren adalah perumusan ulang kurikulum madrasah dengan menggunakan standar kurikulum pesantren.

Sebagai konsep penguatan, Madrasah Berbasis Pesantren secara otomatis meniscayakan reformasi kelembagaan. Artinya, satu sisi Madrasah Berbasis Pesantren menyatu dengan pesantren secara integral (MP), bersinergi dengan pesantren sekitar (MLP) maupun dengan mengadopsi sistem nilai dan kultur pesantren (MSNP). Wujud ideal dari Madrasah Berbasis Pesantren adalah madrasah-pesantren (MP) yang meletakkan pesantren sebagai basis baik sebagai sistem nilai, sistem pendidikan, dan lembaga pendidikan dengan inovasi dan kreasi yang positif. Dalam pola ini, secara kelembagaan, pesantren dan madrasah menyatu dalam lingkaran struktur.

Basis ontologis merujuk khususnya pada tugas pendidikan Islam sebagai pewujud konsep Islam atas ontologi manusia. Basis epistemologis merujuk pada cara pikir keislaman yang lahir dari ontologi Islam dalam perumusan sistem pendidikan Islam. Basis pedagogis merujuk pada pembentukan kurikulum sesuai dengan standar kurikulum pesantren, serta metode pengajaran pesantren sebagai pedagogik pendidikan Islam. Basis institusional merujuk pada pola kelembagaan yang lebih bersifat kultural dari pada formalitas dan menjadikan pola kepemimpinan yang menjadikan kiai sebagai otoritas keilmuan moral, bukan murni otoritas teknis manajerial (kepala sekolah). Serta basis kultural yang merujuk pada penggunaan semua basis sebelumnya, sehingga membuahkan kultur pendidikan Islam baru, yakni kultur pendidikan Islam yang mengakar pada tradisi keIslaman. 
Ihsan

\section{DAFTAR PUSTAKA}

Azra, Azyumardi, 2002, Paradigma Ba ru Pendid ikan Nasional;

Rekonstruksi dan De mo kr at is aj i, Jakarta: Penerbit Buku Kompas. , 2003, Pendidikan Islam Tradisional dalam Transisi dan Mo-dernisasi, Jakarta: Logos. , 2003, Surau: Pendidikan Islam Tradisional dalam Transisi dan Modernisasi, Jakarta: Logos.

Dhofier, Zamakhsyari, 1994, Tradisi Pesantren: Studi Tentang Pandangan Hidup Kyai, Jakarta: LP3ES.

Greg Fealy (ed), 1997, Ahmad Suaedy (terjemahan) Tr adi si on a lisme Rudikal: Persinggungan Nabd latul Ulama-Neg ara Yogyakarta : LKIS.

Guba, E. G. \& Lincoln, Y. S., Effective evaluation,

H.A. Malik Fadjar, 1995, dalam Kontekstualisasi Ajaran Islam 70 Tabun Mu-nawir Sjadzal, Jakarta: kerja sama IPHI dan Paramadina.

Madjid, Nurcholis, ,1997, Bilik-Bilik Pesantren, Jakarta: Paramadina. , Bi lik-Bil ikPesantren Sebuah Potret Peyjalanan, Jakarta:Pa ra ma dina. 
Mastuhu, 1994, Dinamika Sistem Pendidikan Pesantren, Suatu Kajian Tentang Unsur dan Nilai Sistem Pendidikan Pesantren, Jakarta: INIS.

Moestopo, M.Habib, 2001, Kebudayaan Islam di Jawa Timur: Kajian Beberapa Unsur Budaya Masa Peralihan, Yogyakarta: Jendela.

Muhadjir, Noeng, 2002, Metodologi penelitian kebijakan dan evaluation research, Yogyakarta: Rake Sarasin. , 2002, Metodologi Penelitian Kualitatif (Yogjakarta: Rake Sarasin.

Muhaimin, et al., 2002, Paradigma Pendidikan Islam: Upaya Mengefektifkan Pen-didikan Agama Islam di Sekolah, Bandung: PT Remaja Rosda-karya.

Munir Mulkhan, 2002, Nalar Spiritual Pendidikan, Yogya: Tiara Wacana.

Nasution, 1993, Pengembangan Kurikulum (Bandung: PT Citra Aditya Bakti.

Sayono, Joko, 2001, "Historiografi Pesantren: Perspektif Metodologis antara Ada dan Tiada", Makalah.

Sirozi, M., 2005, Politik Pendid ikan; Di namika Hubungan antara

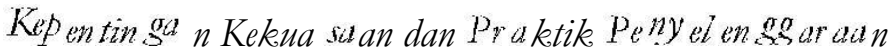
Pendidikan, Jakarta: RajaGrafi ndo Persada.

Steenbrink, K. A., 1986, Pesantren madrasah sekolab: Pendidikan Islam dalam kurun modern, Jakarta: LP3ES. 
Sri Sutjiatiningsih \& Slamet Kutoyo, 1986, Sejarab Pendidikan Daerah Jawa Timur, Surabaya: Proyek Inventarisasi dan Dokumentasi Kebudyaan Daerah.

Sugiyono, 2005, Memahami Penelitian Kualitatif, Bandung: Alfabeta.

Sumber data Kantor Kementerian Agama Kabupaten Kudus tahun 2010.

Supaat, 2009, Model transformasi Madrasah sebagai Sekolab Umum Berciri Khas Islam.

Syed Muhammad Al-Naquib Al-Attas, 1980, The Concept of Education in Islam: A Framework for an Islamic Philosophy of Education Kuala Lumpur: Muslim Youth Movement of Malaysia.

, 1978, Islam and Secularism, Kuala Lumpur: Muslim Youth Movement of Malaysia.

Van Bruinessen, Martin, 1997, Kitab Kuning Pesantren dan Tarekat: Tradisi-Tradisi Islam di Indonesia, Bandung: Mizan, 1995, 17. Paramadina.

Wahid, Marzuki, 1999, Pesantren Masa Depan; Wa cana Pemberday aun dan Transforma si Pe santren, Bandung: Pustaka Hidayah.

Zuhairini, dkk., 1995, Filsafat Pendidikan Islam, Jakarta: Bumi Aksara.

Zuhri, Saefuddin, Pendidikan Pesantren di Persimpangan Ja lan, dalam : Marzuki Wahid(ed), Pesanten Masa Depan” 